BULLETIN OF PNRPU. GEOLOGY. OIL \& GAS ENGINEERING \& MINING

ВЕСТНИК ПНИПУ. ГЕОЛОГИЯ. НЕФТЕГАЗОВОЕ И ГОРНОЕ ДЕЈО

ISSN 2224-9923

Volume/Tom 15 №20 2016

http://vestnik.pstu.ru/geo/

УДК 621.873

Article / Статья

(C) PNRPU / ПНИПУ, 2016

\title{
SYNTHESIS AND STUDY OF QUASIOPTIMAL QUICK ACTING MOVEMENT CONTROL OF LIFTING CRANES WITH A LOAD ON FLEXIBLE SUSPENSION
}

\section{V.S. Loveikin, lu.A. Romasevich}

National University of Life and Environmental Sciences of Ukraine (12 Geroev Oborony str., Kiev, 03127, Ukraine)

\section{СИНТЕЗ И ИССЛЕДОВАНИЕ КВАЗИОПТИМАЛЬНОГО ПО БЫСТРОДЕЙСТВИЮ УПРАВЛЕНИЯ ДВИЖЕНИЕМ ГРУЗОПОДЪЕМНОГО КРАНА С ГРУЗОМ НА ГИБКОМ ПОДВЕСЕ}

\section{В.С. Ловейкин, Ю.А. Ромасевич}

Национальный университет биоресурсов и природопользования Украины (03127, Украина, г. Киев, ул. Героев Обороны, 12)

\author{
Received / Получена: 27.06.2016. Accepted / Принята: 29.08.2016. Published / Опубликована: 30.09.2016
}

\section{Key words:}

lifting crane, quasioptimal control, maximum principle, load fluctuations, dynamic loads, particle swarm method, mathematical model, transcendental equation.

\begin{abstract}
The subject of research is an influence pattern of quasioptimal quick acting movement control of lifting cranes with a load flexible suspension on dynamic movement characteristics. The purpose of the work lies in the synthesis of quasioptimal crane movement control when its accelerating with the elimination of load fluctuations, as well as in the study of the crane movement dynamics at the quasioptimal control.

The paper proposed to switch from an optimal control of crane movements to control, which is described by a continuous function. In order to achieve specified final conditions of movement by the system "crane-load" an algebraic system of transcendental equations was composed, which was leaded to the target of minimizing the complex function of three arguments. By using the particle swarm method points in time were found at which there was a change in the control character (the driving force of the crane actuator). Simulation of crane movements at quasioptimal control made it possible to find its basic dynamic characteristics during acceleration. Comparative analysis of the data showed a significant reduction of dynamic loads in the crane elements. The transitional regime duration of the crane movement in comparison with the optimal control increases slightly. Thus, by increasing the duration of the crane's non-essential movement cycle (for tens of seconds) an increase in the durability of the crane steel structures, mechanical gears, motor, power inverter, and other elements is achieved.

The obtained results should be used for the development and modernization of movement control systems for lifting equipment, which require a significant productivity, energy efficiency and durability (for example, cranes that are extensively exploited in ports, metallurgical and machine-building enterprises, construction sites, warehouses).
\end{abstract}

Ключевые слова: грузоподъемный кран, квазиоптимальное управление, принцип максимума, колебания груза, динамические нагрузки, метод роя частиц, математическая модель, трансцендентные уравнения.
Предметом исследования являются закономерности влияния квазиоптимального по быстродействию управления движением грузоподъемного крана с гибким подвесом груза на динамические характеристики движения. Цель работы заключается в синтезе квазиоптимального управления движением крана при его разгоне с устранением колебаний груза, а также в исследовании динамики движения крана при квазиоптимальном управлении.

В работе предложено перейти от оптимального по быстродействию управления движением крана к управлению, которое описывается с помощью непрерывной функции. Для обеспечения достижения системой «кран-груз» заданных конечных условий движения была составлена система алгебраических трансцендентных уравнений, которую удалось привести к задаче минимизации сложной функции трех аргументов. В результате использования метода роя частиц были найдены моменты времени, в которых происходит изменение знака управления (движущего усилия привода крана). Моделирование движения крана при квазиоптимальном управлении дало возможность найти его основные динамические характеристики при разгоне. Сравнительный анализ полученных данных показал значительное уменьшение динамических нагрузок в элементах крана. При этом длительность переходного режима движения крана в сравнении с оптимальным по быстродействию управлением увеличивается незначительно. Таким образом, путем несущественного увеличения длительности цикла передвижения крана (на десятки долей секунды) достигается увеличение долговечности крановой металлоконструкции, механических передач, двигателя, силового инвертора и других элементов.

Полученные результаты целесообразно использовать для разработки и модернизации систем управления движением грузоподъемных машин, к которым предъявляются требования значительной производительности работы, энергетической эффективности и долговечности (например, для кранов, которые интенсивно эксплуатируются в портах, на металлургических и машиностроительных предприятиях, строительных площадках, складах).

\footnotetext{
Viacheslav S. Loveikin - Doctor of Technical Science, Professor, Head of the Department of Machinery and Equipment Construction (tel.: 0445278734 , e-mail: lovvs@ukr.net).

Iurii A. Romasevich - Doctor of Technical Science, Associate Professor of the Department of Machinery and Equipment Construction (tel.: 0445278734 , e-mail: d.um@mail.ru). The contact person for correspondence.

Ловейкин Вячеслав Сергеевич - доктор технических наук, профессор, заведующий кафедрой конструирования машин и оборудования (тел.: 0445278734 , e-mail: lovvs@ukr.net).

Ромасевич Юрий Александрович - доктор технических наук, доцент кафедры конструирования машин и оборудования (тел.: 0445278734 , e-mail: d.um@mail.ru). Контактное лицо для переписки.
} 


\section{Introduction}

Many lifting cranes operate in conditions of intense cargo flows. For instance, such are the conditions for portal gantries. In this case it is desirable to reduce the cargo movement cycle duration. Therefore it is reasonable to use an optimally quick crane movement control system which is known to have a relay characteristic [1-7]. This causes additional dynamic loads and, as a result, reduces reliability of the lifting machine [8]. To reduce the dynamic strain and not jeopardize the crane performance it is required to perform synthesis of crane movement quasioptimal control.

\section{Relevant study and published research analysis}

In order to identify optimal time of control for the motion of crane with cargo on a flexible suspension it is common to use the maximum principle [1-11], which, however, provides only quantitative information on the type of control function. To identify points of time for switching the controlling action (transition from maximal to minimal control), R.P. Gerasimiak [1] and his successors [2-4] solve sets of transcendental algebraic equations. O.V. Grigorov [5], on top of that, takes into account the limitations related with crane speed and acceleration, as well as the loaded rope deviation from vertical. In order to define the control switching points, study [5] provides the analysis of phase trajectories describing the oscillating movement of load on a flexible suspension.

Study [12] researches the dynamic loads occurring in elastic elements of the pillar crane turning mechanism in the course of a time optimal acceleration of the system. Based on the conducted research, it is proposed to change the controlling function (actuating moment) exponentially; the influence of the exponent time constant on the dynamic response factor of the machine. This approach allows to significantly reduce the dynamic stress of crane mechanisms.

The majority of international researchers dealing with problems of lifting cranes movement optimal control synthesis use linear quadratic regulator synthesis methods [13-21]. The essence of this approach is that the "crane-load" system is presented as an object of regulation, whereby it is required to achieve absence of load oscillation relative to the suspension point. The research allowed formulating optimal regulation laws for the crane mechanism motion. Applying these laws it is possible to eliminate load oscillations on the flexible suspension taking into account the actual oscillation phase and minimize undesirable characteristics of the system's movement presented as integral-type functionals with subintegral quadratic functions.

The reviewed studies lack the solution of the problem of optimal program control synthesis, whereby it is possible to achieve significant time efficiency of the "crane-load" system with simultaneous reduction of dynamic loads in crane elements. This problem is solved by the current research.

\section{Research objective and tasks definition}

The research objective is synthesis and study of time quasioptimal movement control of a crane with load on flexible suspension. In order to achieve this goal, following tasks have to be solved: 1) perform synthesis of time quasioptimal movement control of a crane with load on flexible suspension; 2) study the movement dynamics of crane with load on flexible suspension in the course of time quasioptimal control implementation.

\section{Synthesis and study of time quasioptimal movement control of a crane with load on flexible suspension}

1. Synthesis of time quasioptimal movement control of a crane with load on flexible suspension

In order to conduct the research, first let us assume the dual-mass dynamic crane model with load on flexible suspension depicted in Figure 1.

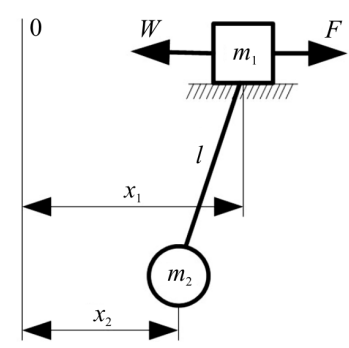

Figure 1. Dynamic dual-mass model of "crane-load" system

High frequency oscillation of the crane steel structure and its actuators do not impact the low frequency oscillations of the load on flexible suspension. Therefor the model depicted in Figure 1 
is rather often used for the crane dynamic calculations $[22,23]$.

Dynamic model shown in Figure 1 is described by the system of differential equations

$$
\left\{\begin{array}{l}
m_{1} \ddot{x}_{1}+m_{2} \ddot{x}_{2}=F-W \text { sign } \dot{x}_{1} \\
\ddot{x}_{2}+\frac{g}{l}\left(x_{2}-x_{1}\right)=0
\end{array}\right.
$$

where $m_{1}$ - forward motion reduced weight of the crane and its actuator; $m_{2}-$ load weight; $x_{1}, x_{2}-$ center of mass coordinates for crane and load, respectively; $F$ - tractive or breaking force applied to the crane; $W$ - reduced crane movement resistance force; $g$-acceleration of gravity; $l-$ flexible suspension length. Let us assume that during crane accelerating or braking movement its speed does not reverse sign, i.e. $\operatorname{sign} \dot{x}_{1}=1$.

For further consideration, let us assume optimal crane movement control as defined in [1, $3,5,6,8,10]$ :

$$
F_{\text {opt }}=\left\{\begin{array}{l}
F_{\max }, \quad 0 \leq t<\tilde{t}_{1} ; \\
-F_{\max }, \tilde{t}_{1} \leq t<\tilde{t}_{1}+\tilde{t}_{2} ; \\
F_{\max }, \tilde{t}_{1}+\tilde{t}_{2} \leq t<\tilde{t}_{1}+\tilde{t}_{2}+\tilde{t}_{3},
\end{array}\right.
$$

where $\tilde{t}_{1}, \tilde{t}_{2}, \tilde{t}_{3}$ - duration of the first, second and third stages of crane acceleration, respectively, in case of optimal control; $F_{\max }$ - maximum actuating force applied to the crane (in this research the assumption is symmetry of control limit values, i.e. maximum control is equal to minimum control with opposite sign). "Crane-load" system control implies that control function (1) has discontinuities step-like transitions from maximum to minimum and vice versa. This feature results in stress of the crane elements (shafts, unions, steel structure) and increased power consumption. To reduce the undesirable effects that occur with time optimal control, it is modified [12], i.e. the system is switched to quasioptimal control. However this does not eliminate soft impacts in mechanical gears, resulting in significant dynamic stress of the crane elements. Obviously to decrease the dynamic forces it is required to use a more smooth function to control crane movement. To this end, the time optimal control movement function $F_{\text {opt }}$ for crane with load on flexible suspension shall be modified, i.e. switched to a continuous function which describes time quasioptimal control of the "craneload" system:

$$
F_{o p t}^{*}=\left\{\begin{array}{l}
-\frac{F_{\max } t(t-2 \Delta t)}{\Delta t^{2}}, 0 \leq t<\Delta t ; \\
F_{\max }, \Delta t \leq t<t_{1}-\Delta t ; \\
-\frac{F_{\max }\left(t-t_{1}\right)\left(t-t_{1}+2 \Delta t\right)}{\Delta t^{2}}, t_{1}-\Delta t \leq t<t_{1} ; \\
\frac{F_{\max }\left(t-t_{1}\right)\left(t-t_{1}-2 \Delta t\right)}{\Delta t^{2}}, t_{1} \leq t<t_{1}+\Delta t ; \\
-F_{\max }, t_{1}+\Delta t \leq t<t_{1}+t_{2}-\Delta t ; \\
F_{\max }\left(t-t_{1}-t_{2}\right)\left(t-t_{1}-t_{2}+2 \Delta t\right) \\
t_{1}+t_{2}-\Delta t \leq t<t_{1}+t_{2} ; \\
-\frac{F_{\max }\left(t-t_{1}-t_{2}\right)\left(t-t_{1}-t_{2}-2 \Delta t\right)}{\Delta t^{2}}, \\
t_{1}+t_{2} \leq t<t_{1}+t_{2}+\Delta t ; \\
F_{\max }, t_{1}+t_{2}+\Delta t \leq t<t_{1}+t_{2}+t_{3}-\Delta t ; \\
-\frac{F_{\max }\left(t-t_{1}-t_{2}-t_{3}\right)\left(t-t_{1}-t_{2}-t_{3}+2 \Delta t\right)}{\Delta t^{2}}, \\
t_{1}+t_{2}+t_{3}-\Delta t \leq t<t_{1}+t_{2}+t_{3},
\end{array}\right.
$$

where $t_{1}, t_{2}, t_{3}$ - duration of the first, second and third stages of crane acceleration, respectively, in case of quasioptimal control; $\Delta t-$ duration of transition from maximum value $F_{\max }$ to zero, which may vary depending on the requirements to smoothness of control change: when function $F_{o p t}^{*}$ smoothness of changing increases, $\Delta t$ increases as well.

Let us describe some of the mathematical properties of the function (3) that influence the dynamics of the system movement. It is worth mentioning that function (3) affords absolute minimums to several integral and terminal functionals:

$$
\left\{\begin{array}{l}
\int_{0}^{t_{1}+t_{2}+t_{3}}\left(\dddot{F}_{o p t}^{*}\right)^{2} d t=a b s \min =0 ; \\
\int_{\Delta t}^{t_{1}-\Delta t}\left(\dot{F}_{o p t}^{*}\right)^{2} d t+\int_{t_{1}+\Delta t}^{t_{1}+t_{2}-\Delta t}\left(\dot{F}_{\text {opt }}^{*}\right)^{2} d t+ \\
+\int_{t_{1}+t_{2}+t_{3}-\Delta t}^{t_{1}+t_{2}+\Delta t}\left(\dot{F}_{o p t}^{*}\right)^{2} d t=a b s \min =0 ; \\
\left(\dot{F}_{o p t}^{*}(\Delta t)\right)^{2}=\left(\dot{F}_{\text {opt }}^{*}\left(t_{1}-\Delta t\right)\right)^{2}= \\
=\left(\dot{F}_{\text {opt }}^{*}\left(t_{1}+\Delta t\right)\right)^{2}=\left(\dot{F}_{o p t}^{*}\left(t_{1}+t_{2}-\Delta t\right)\right)^{2}= \\
=\left(\dot{F}_{\text {opt }}^{*}\left(t_{1}+t_{2}+\Delta t\right)\right)^{2}= \\
=\left(\dot{F}_{\text {opt }}^{*}\left(t_{1}+t_{2}+t_{3}-\Delta t\right)\right)^{2}=a b s \min =0 .
\end{array}\right.
$$

The above functions (4) signify smooth change of force in case of quasioptimal control implementation for movement of crane with load on flexible suspension, reducing the dynamic stress in the crane elements. 
Optimal crane motion control should eliminate crane oscillations at the point of time when it reaches the rated speed. In order to achieve this goal, the following conditions have to be true:

$$
\left\{\begin{array}{l}
\dot{x}_{1}\left(t_{1}+t_{2}+t_{3}\right)=v_{\text {rat }} ; \\
\ddot{x}_{2}\left(t_{1}+t_{2}+t_{3}\right)=\dddot{x}_{2}\left(t_{1}+t_{2}+t_{3}\right)=0,
\end{array}\right.
$$

where $v_{\text {rat }}$ - rated speed of crane movement with load at the end of acceleration. To find the crane movement speed, as well as acceleration and load drawing shock at the point of time $t_{1}+t_{2}+t_{3}$ it is required to integrate the system of differential equations (1) 9 times for each "piece" of function $F_{o p t}^{*}$. At that, the initial conditions of the first stage of "crane-load" system movement corresponding to the first "piece" of $F_{\text {opt }}^{*}$ function are assumed to be equal to zero (movement of "crane-load" system from standstill condition is considered). Generally for all stages of acceleration of the dynamic system "crane-load" the initial conditions of masses movements for the current stage are the final condition for the masses movement on the previous stage. The described calculations are omitted since they are too voluminous for this paper. As a result, the expressions of crane movement speed were obtained, as well as acceleration and load drawing shock at time point $t_{1}+t_{2}+t_{3}$, and the set of equations was formulated (5). Thus, having found the unknown quantities $t_{1}$, $t_{2}$ and $t_{3}$ out of the set of transcendent equations (5), it is possible to eliminate load oscillations in the end of the crane acceleration.

The analytical solution of equation set (5) is problematic. Therefore, the following function was determined:

$$
\begin{gathered}
f=\left(\dot{x}_{1}\left(t_{1}+t_{2}+t_{3}\right)-v_{r a t}\right)^{2}+ \\
+\ddot{x}_{2}^{2}\left(t_{1}+t_{2}+t_{3}\right)+\dddot{x}_{2}^{2}\left(t_{1}+t_{2}+t_{3}\right) .
\end{gathered}
$$

In order to find values of $t_{1}, t_{2}$ and $t_{3}$, at which function (6) achieves its absolute minimum, particle swarm method was used [24]. Its selection can be explained by the simplicity of algorithmization (which is especially important in practical implementation of the formulated quasioptimal control) and insensitivity to local extremums of the studied function $f$. To solve the equation set, 6 particles were used. The solution was found in 10 iterations.
To illustrate the found time quasioptimal control for movement of crane with load on flexible suspension, Figure 2 shows graphic dependencies.

In Figure 2, grey curves correspond to the known control described by function (2), while the black curves correspond to the time quasioptimal control (3). Movement force in Figure 2, $a$ is presented in relative units received by way of dividing the values $F_{\text {opt }}$ and $F_{o p t}^{*}$ by $F_{\max }$. All curves are built for the following values: $l=10 \mathrm{~m}, m_{1}=100 \mathrm{t} ; m_{2}=50 \mathrm{t} ; F_{\max }=$ $=100 \mathrm{kN} ; v_{\text {rat }}=1.2 \mathrm{~m} / \mathrm{s} ; \Delta t=0.2 \mathrm{~s}$.

Analysis of curves displayed in Figure 2 shows that crane movement quasioptimal control (3) is a smooth function without discontinuity of the first and second kind. The load oscillation amplitude is virtually equal in both cases. (see Figure $2, b$ ). In order to establish the advantages of the found quasioptimal control $F_{o p t}^{*}$ over the known $F_{\text {opt }}$ let us perform a thorough analysis of the crane movement dynamics.

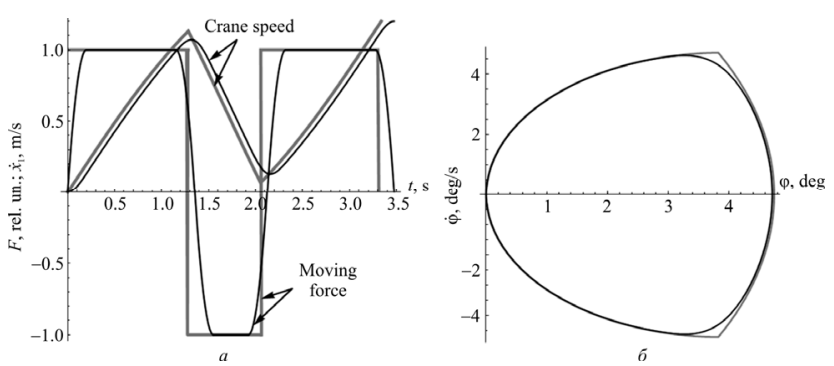

Figure 2. Crane movement dynamics curves at acceleration: $a$-moving force and crane speed; $b$ - phase portrait of load oscillation on flexible suspension

\section{Crane dynamics analysis at quasioptimal} movement control.

Let us estimate the influence of quasioptimal control on the movement dynamics of the crane with load on flexible suspension. To do that, let us consider a more detailed dynamic model of the crane with load on flexible suspension, which takes into account the elastic oscillations of the crane span structure (Figure 3).

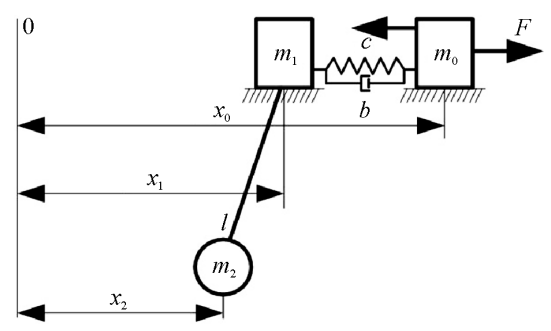

Figure 3. Dynamic three-mass model of "crane-load" system 
Figure 3 introduces the following designations: $c-$ reduced value of crane beams transversal elasticity; $b$ - reduced value of crane beams transversal dissipation factor; $m_{0}, m_{1}, m_{2}-$ forward motion reduced weights of the crane, crane carriage and load, respectively; $x_{0}, x_{1}, x_{2}$ - generalized coordinates of the respective weights. The rest of the designations are analogous to those established in Figure 1. The dynamic model shown in Figure 3 allows estimating the dynamic stress of crane steel structure and establish the nature of high frequency oscillation processes in the crane beam. Movement of the dynamic model shown in Figure 3 is descried by a set of differential equations

$$
\left\{\begin{array}{l}
m_{0} \ddot{x}_{0}+c\left(x_{0}-x_{1}\right)+b\left(\dot{x}_{0}-\dot{x}_{1}\right)=F-\text { Wsign } \dot{x}_{0} ; \\
m_{1} \ddot{x}_{1}+m_{2} \frac{g}{l}\left(x_{1}-x_{2}\right)=c\left(x_{0}-x_{1}\right)+b\left(\dot{x}_{0}-\dot{x}_{1}\right) ; \\
\ddot{x}_{2}+\frac{g}{l}\left(x_{2}-x_{1}\right)=0 .
\end{array}\right.
$$

One of the properties of the found quasioptimal control of crane movement with load on flexible suspension is that when $\Delta t$ increases, the time of transitional processes increases too. Let us estimate the corresponding changes of dynamic stress of the crane beam. To do this, let us introduce a multiplicity index for maximum force in the crane beam:

$$
k=\frac{F_{\max , \text { beam }}^{\text {optimal }}}{F_{\max , \text { beam }}^{\text {quasioptimal }}}
$$

where $F_{\max \text {, beam }}^{\text {optima }}$ И $F_{\text {max, beam }}^{\text {quasional }}$ - values of maximum forces in the beam at optimal $F_{\text {opt }}$ and quasioptimal $F_{\text {opt }}^{*}$ control, respectively. Moreover, we are going to use the integral estimation index:

$$
I=\frac{\sqrt{\frac{1}{\tilde{t}_{1}+\tilde{t}_{2}+\tilde{t}_{3}} \int_{0}^{\tilde{t}_{1}+\tilde{\tau}_{2}+\tilde{t}_{3}}\left(F_{\text {beam }}^{\text {optimal }}\right)^{2} d t}}{\sqrt{\frac{1}{t_{1}+t_{2}+t_{3}} \int_{0}^{t_{1}+t_{2}+t_{3}}\left(F_{\text {beam }}^{\text {quasioptimal }}\right)^{2} d t}},
$$

where $F_{\text {max beam }}^{\text {optimal }}$ и $F_{\text {max beam }}^{\text {quasioptimal }}$ - functions describing the change of force in the crane beam at optimal $F_{\text {opt }}$ and quasioptimal $F_{o p t}^{*}$ control, respectively.

To assess the incremental acceleration time for quasioptimal control let us introduce an index

$$
\Delta T=t_{1}+t_{2}+t_{3}-\left(\tilde{t}_{1}+\tilde{t}_{2}+\tilde{t}\right) .
$$

Terminal index (8) allows estimating the correlation between maximum forces in the crane beam for different types of control of its movement. The correlation between root mean squares for them time of crane acceleration at different types of movement control is estimated with the use of index (9).

Figure 4 shows dependency graphs for indexes $k$, $I$ and $\Delta T$ on value of $\Delta t$, received by modeling of crane movement with load on flexible suspension at optimal $F_{\text {opt }}$ and quasioptimal $F_{\text {opt }}^{*}$ control.

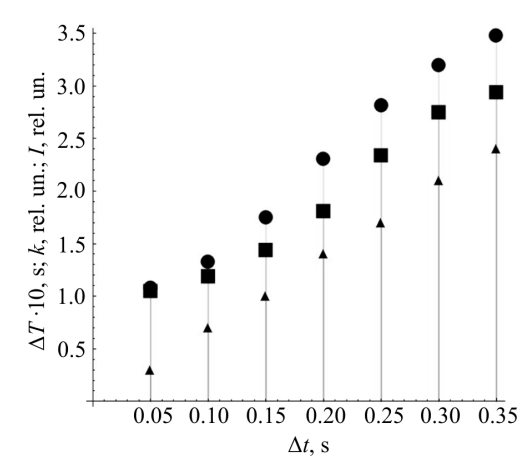

Figure 4. Dependency graphs for indexes

$k(\boldsymbol{\bullet}), I(\bullet)$ и $\Delta T(\mathbf{\Delta})$ on $\Delta t$ value

The analysis of the received graphic dependencies allows making a conclusion: a significant decrease of dynamic stress in the crane steel structure can be achieved even with minor $\Delta t$ values. The calculations of $k, I$ and $\Delta T$ indexes are provided for maximum $\Delta t$ value $=0.35 \mathrm{~s}$. A higher value will disagree with quasioptimal mode of the crane motion. Thus, the crane acceleration has to be performed at maximum $\Delta t$ value, which will allow to significantly decrease the crane dynamic stress and increase its service life.

The formulation of algorithms for maximum $\Delta t$ value calculation at which quasioptimal control of the crane movement is still possible is anticipated in subsequent studies. Besides, the energy indicators of crane movement in case of quasioptimal control are still to be researched.

\section{Summary}

This paper provides a synthesis of time quasioptimal law of movement control for crane with load on flexible suspension, allowing to reduce the dynamic stress carried by the crane steel structure by 2.9-3.5 times. At that, the crane acceleration (or breaking) time increases only by $0.24 \mathrm{~s}$. Besides, the implementation of the found crane movement control is not problematic in terms of actuating, since the quasioptimal law is described by a continuous function of time.

The obtained results are recommended for use in the development of new and retrofit of the existing systems for heavy duty span-type cranes movement control. 


\section{References}

1. Gerasimiak R.P., Leshchov V.A. Analiz i sintez kranovykh elektromekhanicheskikh sistem [Analysis and synthesis of crane electromechanical systems]. Odessa: SMIL, 2008, $192 \mathrm{p}$.

2. Logvinenko K.S. Povyshenie kachestva perekhodnykh protsessov slozhnykh elektromekhanicheskikh sistem kranovykh mekhanizmov [Improving the transient processes quality in complex electromechanical systems of crane mechanisms]: avtoref. dis. ... kand. tekhn. nauk. Odessa, 2003, 24 p.

3. Mel'nikova L.V. Avtomatizatsiia tekhnologicheskogo protsessa peremeshcheniia mekhanizma $\mathrm{s}$ podveshennym gruzom sredstvami mikroprotsessornogo upravleniia [Automation of technological process of mechanism moving with a suspended load by means of the microprocessor control]: dis. ... kand. tekhn. nauk: 05.09.03. Odessa, 2000, $116 \mathrm{p}$.

4. Busher V.V. Asinkhronnyi elektroprivod pod"emnotransportnykh mekhanizmov s mikroprotsessorym upravlenim [Asynchronous electric drive of lifting and transport mechanisms with microprocessor control]: avtoref. dis. ... kand. tekhn. nauk: 05.09.03. Odessa, 1993, $16 \mathrm{p}$.

5. Grigorov O.V. Sovershenstvovanie rabochikh kharakteristik kranovykh mekhanizmov [Improving the performance of crane mechanisms]: dis. ... d-ra tekhn. nauk: 05.05.05. Khar'kov, 1995, $386 \mathrm{p}$.

6. Smekhov A.A., Erofeev N.I. Optimal'noe upravlenie pod"emno-transportnymi mashinami [Optimal control of lifting and transport machinery]. Moscow: Mashinostroenie, 1975, $239 \mathrm{p}$.

7. Poliakov L.N. Razrabotka i issledovanie optimal'noi sistemy upravleniia elektroprivodom kranovoi telezhki [Development and research of optimal motor control system of the crane trolley]: avtoref dis. ... kand tekhn. nauk: 05.09.03. Khar'kov, 1973, 23 p.

8. Chernous'ko F.L., Akulenko L.D., Sokolov B.N. Upravlenie kolebaniiami [Fluctuations management]. Moscow: Nauka, 1980, 384 p.

9. Zaitsev Iu.I. Issledovanie nestatsionarnykh kolebanii i optimal'nye rezhimy raboty gruzopod"emnykh mashin s postupatel'nymi dvizheniiami [Study of unsteady fluctuations and optimal modes of operation of lifting equipment with the translational motion]: dis. ... kand. tekhn. nauk: 01.02.06. Khar'kov, 1981, $259 \mathrm{p}$.

10. Kuntze H.-B. Zur zeitoptimalen Steuerung und Regelung von Laufrranen. Wissenschaftliche Zeitschrift für Verkehrswesen, 1971, no.4, pp.973-990.

11. Braude V.I., Gokhberg M.M., Zviagin I.E. et al. Ed. Gokhberg M.M. Spravochnik po kranam: v 2 tomakh. Tom. 1: Kharakteristiki materialov i nagruzok. Osnovy rascheta kranom, ikh privodov i metallicheskikh konstruktsii [Handbook on cranes: in 2 vol. Vol. 1: Properties of materials and loads. Basis for crane, their drives and metal constructions calculation]. Moscow: Mashinostroenie, 1988, 536 p.

12. Naidenko E.V. Upravlenie asinkhronnym elektroprivodom mekhanizma povorota s podveshennym gruzom [Asynchronous electric drive's control of rotation mechanism with a suspended load]: dis. ... kand. tekhn. nauk: 05.09.03. Odessa, 2009, 149 p.

13. Ahmad M.A., Raja Ismail R.M.T., Ramli M.S., Abdul Ghani N.M., Zawawi M.A. Optimal tracking with sway suppression control for a gantry crane system. European journal of scientific research, 2009, vol.33, no.4, pp.630-641.

14. Ahmad M.A., Nasir A.N.K., Raja Ismail R.M.T., Ramli M.S. Control schemes for input tracking and antisway control of a gantry crane. Australian Journal of basic and applied sciences, 2010, no.4 (8), pp.2280-2291.

15. Miyata N., Ukita T., Nishioka M., Monzen T., Toyohara T. Development of feedforward anti-sway control for highly efficient and safety crane operation. Mitsubishi Heavy Industries, Ltd. Technical Review, 2001, vol.38, no.2, pp.73-77.

16. Yoshiaki O., Kono S., Uchida K., Fujii T., Monzen T. Development of vibration control system on container crane girder. Mitsubishi Heavy Industries, Ltd. Technical Review, 1997, vol. 34, no.3, pp.105-109.

17. Yoshida Y. Feedback control and time-optimal control about overhead crane by visual servo and these combination control. Intelligent Mechatronics. Rijeka, 2011, pp.103-118.

18. Tanaka S., Kouno S. Automatic measurement and control of the attitude of crane lifters lifter-attitude measurement and control. Control Engineering Practice, 1998, is.9, vol.6, pp.1099-1107. DOI: 10.1016/S09670661(98)00104-X.

19. Konishi Y., Araki N., Tanaka Y., Ishigaki H. Control of container crane by binary input using mixed logical dynamical system. ICIC Express Letters, 2008, vol.2, no.4, pp.415-419. DOI: 10.1109/ICCAS.2008.4694521.

20. Pauluk M., Korytowski A., Turnau A., Szymkat M. Time optimal control of 3d crane. Krakow, 2002, 6 p.

21. Golafshani A.R. Modeling and optimal control of tower crane motions: the thesis requirement for the degree of Doctor of Philosophy in Electrical Engineering. Ontario, 1999, $119 \mathrm{p}$.

22. Kazak S.A. Dinamika mostovykh kranov [Dynamics of bridge cranes]. Moscow: Mashinostroenie, 1968, $331 \mathrm{p}$.

23. Lobov N.A. Dinamika gruzopod"emnykh kranov [Dynamics of lifting cranes]. Moscow: Mashinostroenie, $1987,160 \mathrm{p}$.

24. Kennedy J., Eberhart R.C. Particle swarm optimization. Proceedings of IEEE International Conference on Neural Networks. Perth, 1995, pp.1942-1948. 


\section{Список литературы}

1. Герасимяк Р.П., Лещёв В.А. Анализ и синтез крановых электромеханических систем. - Одесса: СМИЛ, 2008. - 192 с.

2. Логвиненко К.С. Підвищення якості перехідних процесів складних електромеханічних систем кранових механізмів: автореф дис. на здоб. ступ. канд. техн. наук. - Одесса, 2003. - 24 с.

3. Мельникова Л.В. Автоматизация технологического процесса перемещения механизма с подвешенным грузом средствами микро-

процессорного управления: дис. ... канд. техн. наук: 05.09.03. - Одесса, 2000. - 116 с.

4. Бушер В.В. Асинхронный электропривод подъемно-транспортных механизмов с микропроцессорным управлением: автореф. дис. ... канд. техн. наук: 05.09.03. - Одесса, 1993. - 16 с.

5. Григоров О.В. Совершенствование рабочих характеристик крановых механизмов: дис. ... д-ра техн. наук: 05.05.05. - Харьков, 1995. - 386 с.

6. Смехов А.А., Ерофеев Н.И. Оптимальное управление подъемно-транспортными машинами. М.: Машиностроение, 1975. - 239 с.

7. Поляков Л.Н. Разработка и исследование оптимальной системы управления электроприводом крановой тележки: автореф дис. ... канд техн. наук: 05.09.03. - Харьков, 1973. - 23 с.

8. Черноусько Ф.Л., Акуленко Л.Д., Соколов Б.Н. Управление колебаниями. - М.: Наука, 1980. - 384 с.

9. Зайцев Ю.И. Исследование нестационарных колебаний и оптимальные режимы работы грузоподъемных машин с поступательными движениями: дис. ... канд. техн. наук: 01.02.06. - Харьков, 1981. - 259 с.

10. Kuntze H.-B. Zur zeitoptimalen Steuerung und Regelung von Laufrranen // Wissenschaftliche Zeitschrift für Verkehrswesen. - 1971. - № 4. - S. 973-990.

11. Справочник по кранам: в 2 т. Т. 1: Характеристики материалов и нагрузок. Основы расчета кранов, их приводов и металлических конструкций / В.И. Брауде, М.М. Гохберг, И.Е. Звягин [и др.]; под. общ. ред. М.М. Гохберга. - М.: Машиностроение, 1988. - 536 с.

12. Найденко Е.В. Управление асинхронным электроприводом механизма поворота с подвешенным грузом: дис. ... канд. техн. наук: 05.09.03. - Одесса, 2009. -149 c.
13. Optimal tracking with sway suppression control for a gantry crane system / M.A. Ahmad, R.M.T. Raja Ismail, M.S. Ramli, N.M. Abdul Ghani, M.A. Zawawi // European journal of scientific research. - 2009. - Vol. 33, № 4. - P. 630-641.

14. Control schemes for input tracking and anti-sway control of a gantry crane / M.A. Ahmad, A.N.K. Nasir, R.M.T. Raja Ismail, M.S. Ramli // Australian Journal of basic and applied sciences. - 2010. - № 4 (8). - P. 2280-2291.

15. Development of feedforward anti-sway control for highly efficient and safety crane operation / N. Miyata, T. Ukita, M. Nishioka, T. Monzen, T. Toyohara // Mitsubishi Heavy Industries, Ltd. Technical Review. 2001. - Vol. 38, № 2. - P. 73-77.

16. Development of vibration control system on container crane girder / O. Yoshiaki, S. Kono, K. Uchida, T. Fujii, T. Monzen // Mitsubishi Heavy Industries, Ltd. Technical Review. - 1997. - Vol. 34, № 3. - P. 105-109.

17. Yoshida Y. Feedback control and time-optimal control about overhead crane by visual servo and these combination control // Intelligent Mechatronics. - Rijeka, 2011. - P. 103-118.

18. Tanaka S., Kouno S. Automatic measurement and control of the attitude of crane lifters lifter-attitude measurement and control // Control Engineering Practice. 1998. - Is. 9, vol. 6. - P. 1099-1107. DOI: 10.1016/S09670661(98)00104-X.

19. Control of container crane by binary input using mixed logical dynamical system / Y. Konishi, N. Araki, Y. Tanaka, H. Ishigaki // ICIC Express Letters. 2008. - Vol. 2, № 4. - P. 415-419. DOI: 10.1109/ICCAS.2008.4694521.

20. Time optimal control of $3 \mathrm{~d}$ crane / M. Pauluk, A. Korytowski, A. Turnau, M. Szymkat. - Krakow, 2002. - 6 s.

21. Golafshani A.R. Modeling and optimal control of tower crane motions: the thesis requirement for the degree of Doctor of Philosophy in Electrical Engineering. Ontario, 1999. - 119 p.

22. Казак С.А. Динамика мостовых кранов. - М.: Машиностроение, 1968. - 331 с.

23. Лобов Н.А. Динамика грузоподъемных кранов. - М.: Машиностроение, 1987. - 160 с.

24. Kennedy J., Eberhart R.C. Particle swarm optimization // Proceedings of IEEE International Conference on Neural Networks. Perth, 1995. - P. 1942-1948.

Please cite this article in English as:

Loveikin V.S., Romasevich Iu.A. Synthesis and study of quasioptimal quick acting movement control of lifting cranes with a load on flexible suspension. Bulletin of PNRPU. Geology. Oil \& Gas Engineering \& Mining, 2016, vol.15, no.20, pp.286-292. DOI: $10.15593 / 2224-9923 / 2016.20 .9$

Просьба ссылаться на эту статью в русскоязычных источниках следующим образом:

Ловейкин В.С., Ромасевич Ю.А. Синтез и исследование квазиоптимального по быстродействию управления движением грузоподъемного крана с грузом на гибком подвесе // Вестник Пермского национального исследовательского политехнического университета. Геология. Нефтегазовое и горное дело. - 2016. - Т.15, №20. - C.286-292. DOI: 10.15593/2224-9923/2016.20.9 